\title{
EFFECT OF ALTERNATIVE HEAT-TREATMENT PARAMETERS ON THE AGING BEHAVIOR OF SHORT-FIBER-REINFORCED 2124 Al COMPOSITES
}

\author{
VPLIV ALTERNATIVNIH PARAMETROV TOPLOTNE OBDELAVE \\ NA STARANJE 2124 Al KOMPOZITA, OJAČANEGA S KRATKIMI \\ VLAKNI
}

\author{
Yahya Altunpak1, Serdar Aslan², Mehmet Oğuz Güler², Hatem Akbulut ${ }^{2}$ \\ ${ }^{1}$ Abant Izzet Baysal University, Faculty of Engineering and Architecture, Mechanical Engineering, 14280 Bolu, Turkey \\ ${ }^{2}$ Sakarya University, Faculty of Engineering, Department of Metallurgy and Materials Engineering, Esentepe Campus, 54187 Adapazari, Turkey \\ altunpak_y@ibu.edu.tr
}

Prejem rokopisa - received: 2015-09-10; sprejem za objavo - accepted for publication: 2015-11-24

doi:10.17222/mit.2015.287

The $2124 \mathrm{Al}$ alloy and a composite of the $2124 \mathrm{Al}$ alloy reinforced with $20 \%$ of volume fractions of $\delta$ - $\mathrm{Al}_{2} \mathrm{O}_{3}$ short fibers made by squeeze casting were subjected to controlled and systematic aging treatments. The materials were solution treated at $(495$ 525 and 555) ${ }^{\circ} \mathrm{C}$. After quenching, the matrix alloy and the composite were artificially aged at $(160,170,180$ and 190$){ }^{\circ} \mathrm{C}$ up to $36 \mathrm{~h}$. The aging was monitored with hardness measurements and differential scanning calorimetry. The time required to reach the peak hardness of the composite matrix during a precipitation treatment was shorter than that for the unreinforced $2124 \mathrm{Al}$. An increase in the solution-treatment temperature resulted in an increase of the composite-matrix hardness. The $\delta$ - $\mathrm{Al}_{2} \mathrm{O}_{3}$-reinforced composite exhibits no grain-boundary melting, but appears to show incipient melting around short alumina fiber interfaces at temperatures above $525^{\circ} \mathrm{C}$. The highest $\mathrm{HV}$ value was obtained after solutionizing at $495^{\circ} \mathrm{C}$ for $6 \mathrm{~h}$, followed by water quenching and aging at $190{ }^{\circ} \mathrm{C}$ for $10 \mathrm{~h}$ for the unreinforced matrix alloy. In the case of the reinforced alloy the highest $\mathrm{HV}$ value was found after solutionizing at $555^{\circ} \mathrm{C}$ for $6 \mathrm{~h}$, quenching and aging at $170{ }^{\circ} \mathrm{C}$ for $12 \mathrm{~h}$.

Keywords: aluminum matrix composite, alumina, solution temperature, aging kinetics

Al zlitina 2124 in kompozit Al zlitine 2124, ojačane z $20 \%$ volumenskega deleža kratkih vlaken $\delta$ - $\mathrm{Al}_{2} \mathrm{O}_{3}$, ulitih z iztiskanjem, so bile kontrolirano in sistematično starane. Materiali so bili raztopno žarjeni na $(495,525$ in 555$){ }^{\circ} \mathrm{C}$. Po hitrem ohlajanju sta bili osnovna zlitina in kompozit umetno starani $36 \mathrm{~h}$ na $(160,170,180$ in 190$){ }^{\circ} \mathrm{C}$. Staranje je bilo kontrolirano $\mathrm{z}$ merjenjem trdote in $z$ diferenčno vrstično kalorimetrijo. Cas za doseganje najvišje trdote kompozitnega materiala med postopkom izločanja je bil krajši kot pri osnovnem materialu Al 2124. Povišanje temperature raztopnega žarjenja se je odrazilo na povečanju trdote kompozita. Kompozit, ojačan z $\delta-\mathrm{Al}_{2} \mathrm{O}_{3}$, ne kaže nataljevanja po mejah zrn, vendar pa kaže zametke taljenja na stiku s kratkimi vlakni, pri temperaturah nad $525^{\circ} \mathrm{C}$. Najvišja vrednost $\mathrm{HV}$ neojačane zlitine je bila dobljena po 6 urnem raztopnem žarjenju na $495^{\circ} \mathrm{C}$, ki mu je sledilo hlajenje v vodi in 10 urno staranje na $190^{\circ} \mathrm{C}$. V primeru kompozitne zlitine je bila zabeležena najvišja $\mathrm{HV}$ vrednost po raztopnem žarjenju $6 \mathrm{~h}$ na $555^{\circ} \mathrm{C}$, ohlajanju v vodi in 12 urnem staranju na $170{ }^{\circ} \mathrm{C}$.

Ključne besede: kompozit na osnovi aluminija, aluminijev oksid, temperatura raztapljanja, kinetika staranja

\section{INTRODUCTION}

Research efforts on aluminum alloys are focused on precipitation phenomena in which the precipitates formed from a supersaturated solution are responsible for the hardening by natural or artificial ageing in an alloy. The response of an aluminum-matrix composite to aging can be completely different from that of the unreinforced alloy. ${ }^{1-8}$ Hence, the age-hardening behavior of particulate-reinforced aluminum composites has been the subject of great interest from the scientific and technological viewpoints. The nature of the change in the hardening kinetics during the aging of composites depends on the matrix material, the type of reinforcement including their size, morphology and volume fraction, composite processing route, solution and aging temperatures. ${ }^{9-12}$

The pressure applied during solidification in the squeze-casting technique results in excellent feeding during solidification shrinkage. The commercialization of squeeze casting has only been used to fabricate highintegrity engineering components with reinforcement very recently. ${ }^{13-15}$

Different types of intermetallics were reported in the solidified 2xxx Al alloys. K. C. Chen and C. G. Chao ${ }^{3}$ found $\mathrm{Cu}_{2} \mathrm{Mn}_{3} \mathrm{Al}_{20}$ intermetallic particles in the 2024 matrix alloy and its $\delta-\mathrm{Al}_{2} \mathrm{O}_{3}$ short-fiber-reinforced composites. The same intermetallic phase was also reported by T. Christman and S. Suresh ${ }^{16}$ in a $2014 \mathrm{Al}$ alloy. On the other hand, C. Badini et al. ${ }^{17}$ showed the possibility of the formation of $\mathrm{Cu}_{2} \mathrm{FeAl}_{7}$ and $(\mathrm{CuFeMn}) \mathrm{Al}_{6}$ in the 2618 Al SiC particle-reinforced composite. The same authors detected $(\mathrm{CuFeMn}) \mathrm{Al}_{6}$ in the $2024 \mathrm{Al}$ alloy and its composite derived from MnAl6. They pointed out that this precipitate did not grow during aging and was not affected by the solution treatment because of its large size. Aluminum alloys with a copper:magnesium weight ratio of 2:1 and higher are used for manufacturing a 
variety of age-hardenable structural alloys. The structural changes that occur during the aging of these alloys have been extensively studied. ${ }^{16-19}$ According to S. K. Varma et al. ${ }^{18}$ and A. P. Sanino and H. J. Rack ${ }^{19}$, the precipitation sequence in the pseudo-binary $\mathrm{Al}-\mathrm{Al}_{2} \mathrm{CuMg}$ alloy (Al-3\% of mass fractions of $\mathrm{Cu}-1.5 \%$ of mass fractions of $\mathrm{Mg}$ ) can be represented as follows in Equation (1):

$$
\begin{gathered}
\text { SSS (supersaturated solid solution) } \rightarrow \\
\text { GPB zones } \rightarrow \mathrm{S}^{\prime \prime} \rightarrow \mathrm{S}^{\prime} \rightarrow \mathrm{S}
\end{gathered}
$$

The solutionizing at $495{ }^{\circ} \mathrm{C}$ for $2-6 \mathrm{~h}$, subsequent quenching and precipitation at $190{ }^{\circ} \mathrm{C}$ for $8-12 \mathrm{~h}$, is defined as the standard heat treatment for the $2124 \mathrm{Al}$ alloy. ${ }^{20}$ It is an age-hardenable alloy, whose mechanical properties are mainly controlled with the hardening precipitates contained in the material. Accordingly, the present work was undertaken to study the effect of the $\delta-\mathrm{Al}_{2} \mathrm{O}_{3}$ short fibers on the aging response of the composite matrix. Particular emphasis was given to examine the effect of the solution treatment and aging temperature on the age-hardening kinetics.

\section{EXPERIMENTAL PART}

The 2124 aluminum matrix alloy and the Saffil fiber/2124 aluminum (4.2 Cu, $1.5 \mathrm{Mg}, 0.6 \mathrm{Mn}, 0.3 \mathrm{Fe}$, $0.25 \mathrm{Zn}$, in mass fractions) composite were produced by squeeze casting using $20 \%$ volume fractions of $\delta-\mathrm{Al}_{2} \mathrm{O}_{3}$ preforms supplied by I.C.I. The preform cohesion was ensured by the addition of 3-4\% silica binder. The preform was supplied in the form of discs with $100 \mathrm{~mm}$ in diameter and $10 \mathrm{~mm}$ in thickness. The liquid aluminum alloy was squeezed into the preform at $800{ }^{\circ} \mathrm{C}$ with a $60 \mathrm{MPa}$ hydraulic press to produce the composites. The pressure holding time was $75 \mathrm{~s}$, to eliminate shrinkage during the solidification. Specimens were solution treated at three different temperatures of $(495,525$ and 555) ${ }^{\circ} \mathrm{C}$ for $6 \mathrm{~h}$. Thereafter, all the specimens were quenched into the water ice brine $\left(-15^{\circ} \mathrm{C}\right)$. The aging treatment was carried out in an electrical furnace at (160, 170, 180 and 190$){ }^{\circ} \mathrm{C}$ up to $36 \mathrm{~h}$. Microhardness measurements of the matrix and the composites (between the fibers) were performed using a diamond pyramid indenter and a 25-g mass. At least 6 hardness measurements were carried out for each aging condition to ensure accurate results.

A group of specimens from the alloy solution treated $2124 \mathrm{Al}$ matrix and the $2124+20 \%$ of volume fractions of $\delta-\mathrm{Al}_{2} \mathrm{O}_{3}$ composite were immediately stored in a refrigerator at $-15{ }^{\circ} \mathrm{C}$. Discs $(5 \mathrm{~mm}$ diameter and $0.3 \mathrm{~mm}$ thickness) for DSC measurements were prepared. The differential scanning calorimetry (DSC) analyses of these samples were performed using a Perkin-Elmer DSC 1700 thermal analyzer. All the samples were loaded in a DSC cell at room temperature and equilibrated for a few minutes. The heating rate was $10 \mathrm{~K} / \mathrm{min}$ from $25^{\circ} \mathrm{C}$ to $550{ }^{\circ} \mathrm{C}$. Dry pure nitrogen was purged through the cell at a rate of $55 \mathrm{~cm}^{3} / \mathrm{min}$ to avoid oxidation. The data for all the DSC runs were recorded in the instrument memory. At least two samples of each heat treatment were analyzed.

Microstructural observations were performed on mechanically polished and etched samples of the unreinforced alloy and composite. Surface-characterization studies were carried out using a Hitachi HHS-2R scanning electron microscope (SEM) with energy-dispersive spectroscopy (EDS).

\section{RESULTS AND DISCUSSION}

\subsection{Microstructural aspects}

At $525{ }^{\circ} \mathrm{C}$ and $555{ }^{\circ} \mathrm{C}$ the solution treatment both alloys showed surface blistering. However, the amount of blistering was more pronounced on the solution treated and quenched unreinforced alloy. These blisters were caused by a high internal gas pressure. Typical representative microstructures of the unreinforced alloy solution treated at $\left(495,525\right.$ and 555) ${ }^{\circ} \mathrm{C}$ and subsequently quenched are shown in Figures 1a to 1c and Figures 2a to 2c shows the light-microscope microstructures of the reinforced composite. All the polished samples were slightly etched with Kellers' agent to reveal grain boundaries and the dissolved intermetallics. Light microscope investigations of the samples of unreinforced alloy have revealed that significant incipient melting along the grain boundaries occurred when the solution heat treatment was at $525{ }^{\circ} \mathrm{C}$ and $555{ }^{\circ} \mathrm{C}$ (Figures $\mathbf{1 b}$ and $\mathbf{1 c}$ ). The $\delta$ - $\mathrm{Al}_{2} \mathrm{O}_{3}$-reinforced composite exhibits no such grain-
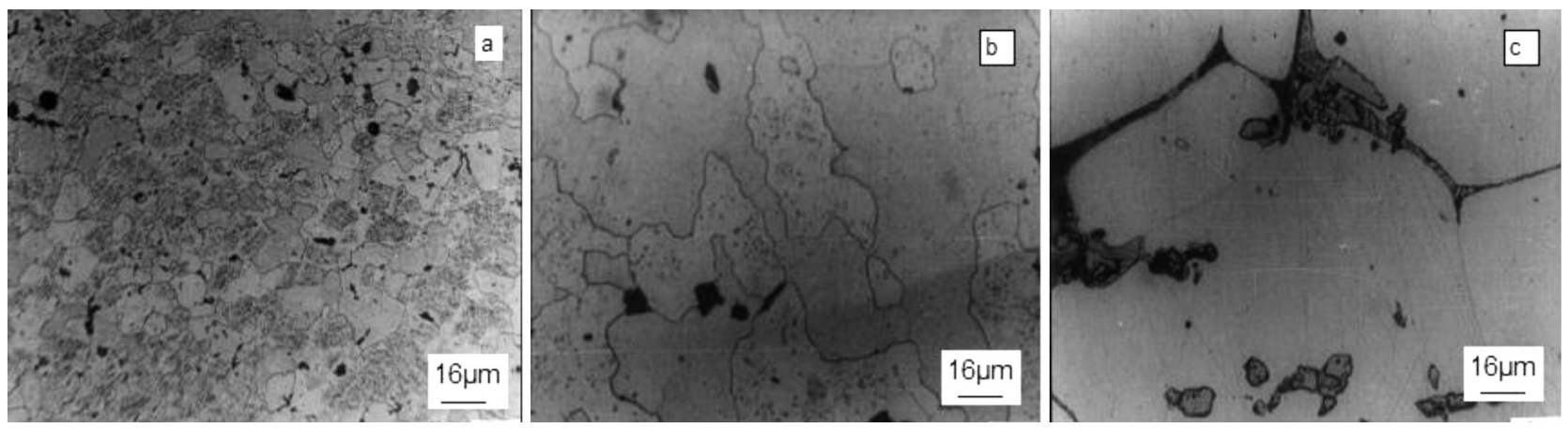

Figure 1: Light micrographs of the unreinforced $2124 \mathrm{Al}$ matrix solution treated at: a) $495{ }^{\circ} \mathrm{C}$, b) $525{ }^{\circ} \mathrm{C}$, and c) $555^{\circ} \mathrm{C}$

Slika 1: Mikrostrukture neojačane Al zlitine 2124 , raztopno žarjene na: $495^{\circ} \mathrm{C}$, b) $525^{\circ} \mathrm{C}$ in c) $555^{\circ} \mathrm{C}$ 

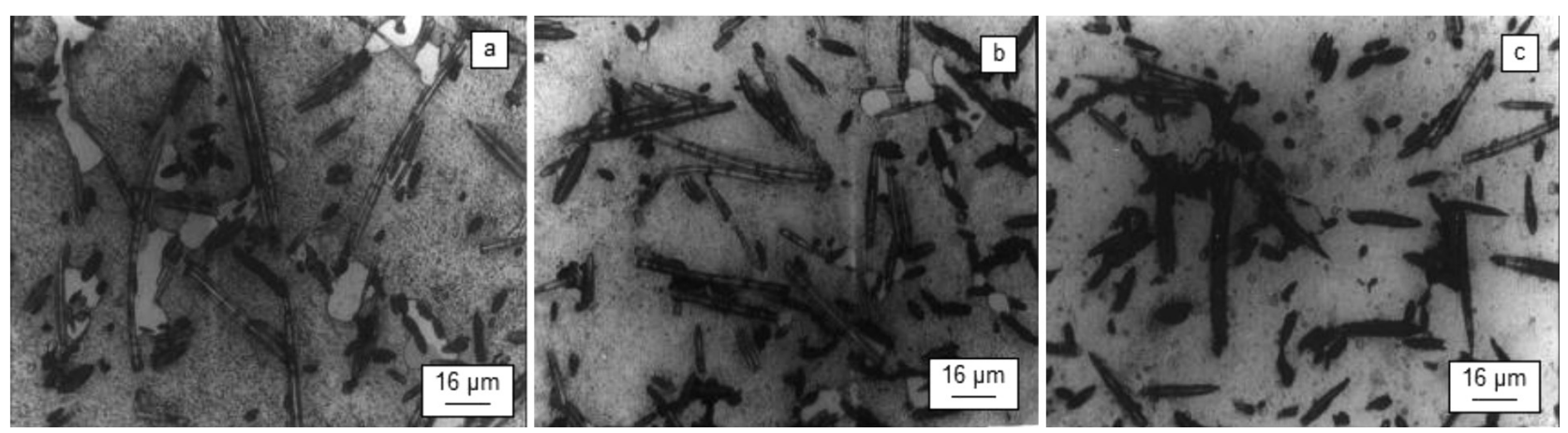

Figure 2: Light micrographs of the $2124 \mathrm{Al}+20 \%$ volume fractions of $\delta$ - $\mathrm{A} 1_{2} \mathrm{O}_{3}$ composite solution treated at: a) $495{ }^{\circ} \mathrm{C}$, b) $525{ }^{\circ} \mathrm{C}$, and c) $555{ }^{\circ} \mathrm{C}$ Slika 2: Mikrostrukture Al kompozita $2124+20 \%$ volumenskega deleža $\delta$ - $\mathrm{A} 1_{2} \mathrm{O}_{3}$, raztopno žarjenega na: a) $495{ }^{\circ} \mathrm{C}$, b) $525{ }^{\circ} \mathrm{C}$ in c) $555{ }^{\circ} \mathrm{C}$

boundary melting, but appears to show incipient melting around the short alumina-fiber interfaces (Figures 2b and $\mathbf{2 c}$ ). There are low-melting-point constituents, which melt first at temperatures above the initial melting point of an alloy producing incipient melting and embrittlement. Thus, it appears that whilst these low-meltingpoint constituents segregate to the grain boundaries in the unreinforced alloy they may segregate to $\delta-\mathrm{Al}_{2} \mathrm{O}_{3}$ short fiber interfaces. Figures $\mathbf{1}$ and $\mathbf{2}$ show that as the solution treatment temperature is increased the amount of intermetallic appearing on the polished and etched surface decreases. The unreinforced alloy does not exhibit a visible intermetallic at any of the solution temperatures studied. The reduction in the intermetallics appearing on the polished surface as the solution temperature increase (Figure 2) is due to the dissolution of intermetallic particles. In order to clarify the undissolved phase, an SEM-EDS study was undertaken. Figure 3 shows a typical EDS spectrum performed on the undissolved phase in the composite matrix. From the EDS analysis copper, magnesium, aluminum, manganese, and iron peaks were observed on the undissolved phase in the heat-treated, unreinforced and composite matrix. For the EDS analysis of the undissolved phase the average elemental concentrations of these undissolved phases and the spectral analyses of the matrix material (2124 Al) were given in Table 1. It is clear that the contents of copper and manganese of the undissolved phase are much higher than those of the matrix material. The undissolved phase in the literature was identified as $\mathrm{Cu}_{2} \mathrm{Mn}_{3} \mathrm{Al}_{20}$, which was also found in $2024 \mathrm{Al}$ by K. C. Chen and C. G. Chao ${ }^{3}$ and in 2014 Al by T. Christman and S. Suresh. ${ }^{16}$

Table 1: Spectral analysis and EDS analysis results, in mass fractions $(w / \%)$

Tabela 1: Rezultati spektralne in EDS-analiz, v masnih deležih (w/\%)

\begin{tabular}{|l|c|c|c|c|c|c|}
\hline & $\mathrm{Cu}$ & $\mathrm{Mg}$ & $\mathrm{Mn}$ & $\mathrm{Fe}$ & $\mathrm{Zn}$ & $\mathrm{Al}$ \\
\hline $\begin{array}{l}\text { 2124 Al alloy spectral } \\
\text { analyses results }\end{array}$ & 4.2 & 1.5 & 0.6 & 0.3 & 0.25 & $\begin{array}{l}\text { Bal- } \\
\text { ance }\end{array}$ \\
\hline $\begin{array}{l}\text { EDS analysis results of } \\
\text { the undissolved phase in } \\
\text { unreinforced matrix }\end{array}$ & 7.55 & 0.15 & 9.05 & 0.04 & & 83.2 \\
\hline $\begin{array}{l}\text { EDS analysis results of } \\
\text { the undissolved phase in } \\
\text { the composite matrix }\end{array}$ & 7.52 & 0.13 & 9.20 & 0.05 & & 83.1 \\
\hline
\end{tabular}

\subsection{DSC analysis}

The DSC scans of the unreinforced 2124 alloy and $2124 \mathrm{Al}+20 \%$ volume fractions of $\delta-\mathrm{Al}_{2} \mathrm{O}_{3}$ composite are shown in Figure 4. For comparison purposes, results from the DSC scans of the unreinforced matrix and the composite quenched into ice brine after the solution treatment at $495{ }^{\circ} \mathrm{C}$ and $555^{\circ} \mathrm{C}$ are presented in Figures $\mathbf{4 a}$ and $\mathbf{4 b}$, respectively. The DSC traces of the composites were different from each other. However, the DSC
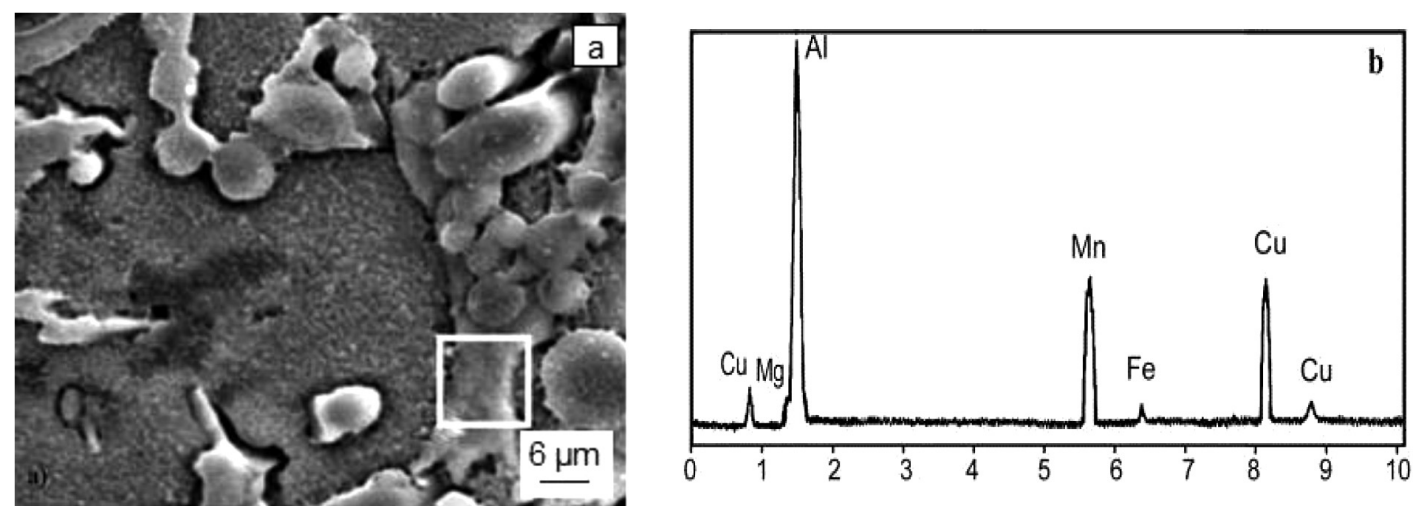

Figure 3: a) SEM micrograph of the $2124 \mathrm{Al}+20 \%$ volume fractions of $\delta$ - $\mathrm{Al}_{2} \mathrm{O}_{3}$ composite and b) an EDS spectrum taken from the undissolved intermetallic phase

Slika 3: a) SEM-posnetek Al kompozita $2124+20 \%$ volumenskega deleža $\delta-\mathrm{Al}_{2} \mathrm{O}_{3}$ in b) EDS- spekter neraztopljene intermetalne faze 

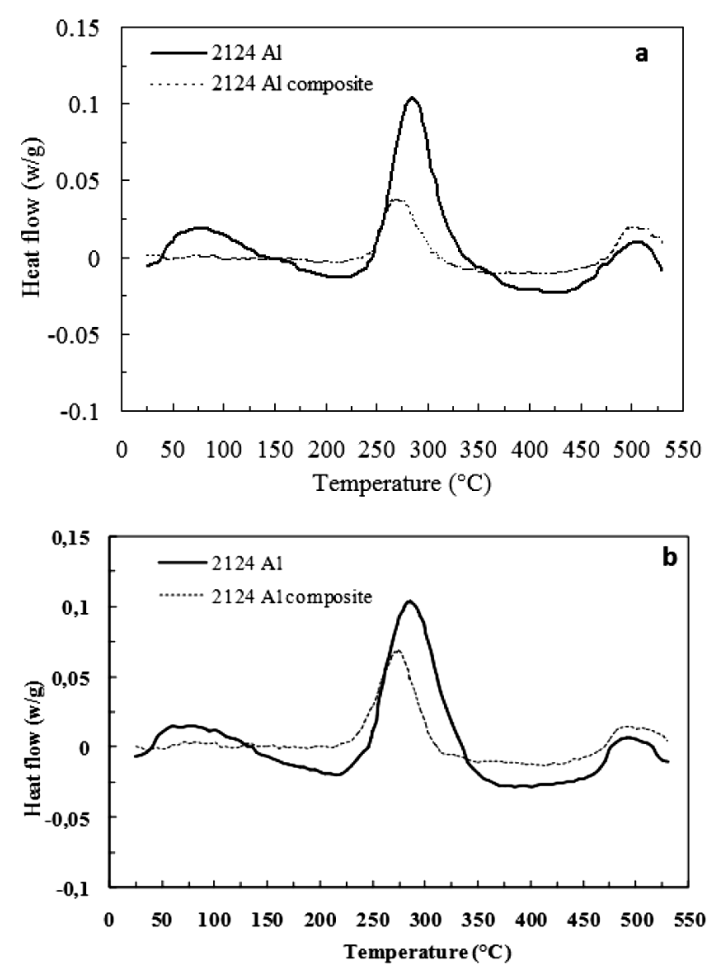

Figure 4: Results of DSC for $2124 \mathrm{Al}$ alloy and $2124 \mathrm{Al}$ alloy $+20 \%$ volume fractions of $\delta-\mathrm{Al}_{2} \mathrm{O}_{3}$ composite solution treated at: a) $495{ }^{\circ} \mathrm{C}$ and b) $555^{\circ} \mathrm{C}$

Slika 4: Rezultati DSC Al zlitine 2124 in Al kompozita $2124+20 \%$ volumenskega deleža $\delta-\mathrm{Al}_{2} \mathrm{O}_{3}$, po raztopnem žarjenju na: a) $495{ }^{\circ} \mathrm{C}$ in b) $555{ }^{\circ} \mathrm{C}$

traces of the matrix alloy do not exhibit significant differences depending on the solutionizing temperatures. The curve of the unreinforced matrix alloy shows four zones: an exothermic reaction between $40{ }^{\circ} \mathrm{C}$ and $135^{\circ} \mathrm{C}$ due to the formation of Guiner-Preston zones followed by an endothermic between $135^{\circ} \mathrm{C}$ and $245^{\circ} \mathrm{C}$ due to the dissolution of the Guiner-Preston zones; an exothermic reaction between $245{ }^{\circ} \mathrm{C}$ and $335{ }^{\circ} \mathrm{C}$ due to formation of S' precipitates and finally the endothermic reaction between $335{ }^{\circ} \mathrm{C}$ and $485{ }^{\circ} \mathrm{C}$ due to the dissolution of these $S^{\prime}$ precipitates (Figures $\mathbf{4 a}$ and $\mathbf{4 b}$ ). However, the DSC curves for the composite do not have obvious Guiner-Preston zone formation and dissolution peaks. Increasing the solution temperature to $555^{\circ} \mathrm{C}$ resulted in an increase in the amount of $S^{\prime}$ precipitate for the composite, as shown in Figures $\mathbf{4 a}$ and $\mathbf{4 b}$. Additionally, the figure also shows an acceleration of $S$ ' precipitate formation in the case of the reinforced alloy. For example, the $S^{\prime}$ precipitates are formed at $245{ }^{\circ} \mathrm{C}$ in the unreinforced $2124 \mathrm{Al}$ matrix (Figure 4a), but this temperature is approximately $230{ }^{\circ} \mathrm{C}$ for the composite material (Figure 4b). This shows that the short $\delta-\mathrm{Al}_{2} \mathrm{O}_{3}$ ceramic phase shifted the $\mathrm{S}^{\prime}$ precipitate-formation temperature.

\subsection{Matrix microhardness}

Figure 5 shows the microhardness (HV) as a function of aging time at $190{ }^{\circ} \mathrm{C}$ for both alloys. For all con-
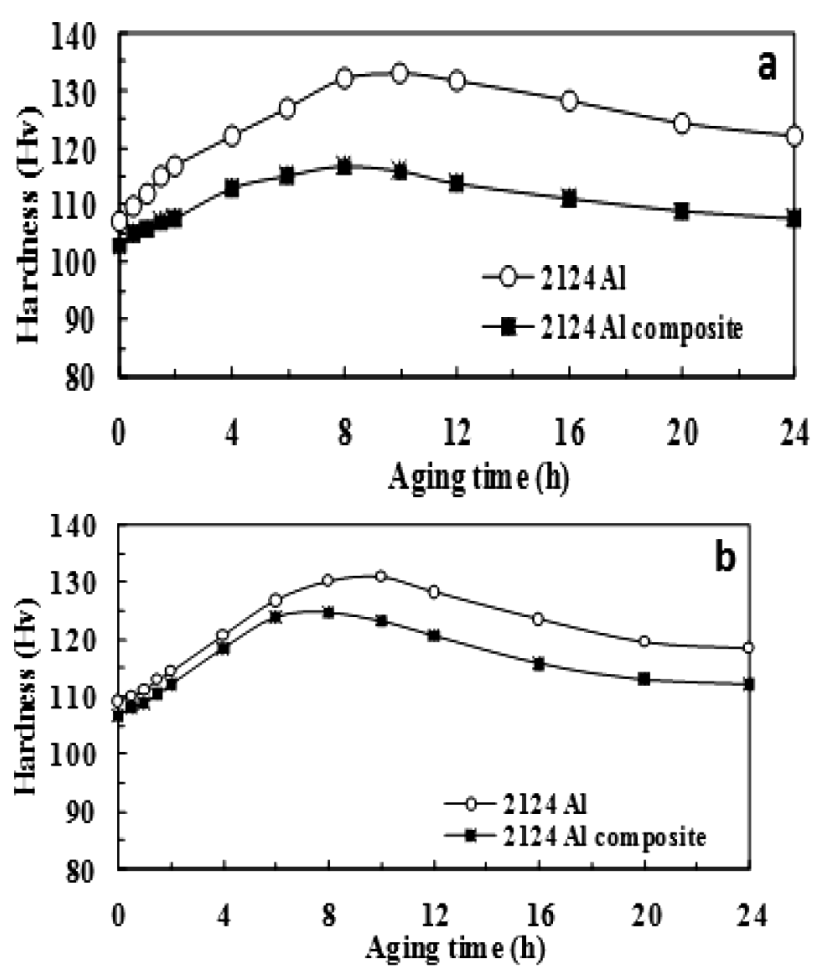

Figure 5: Microhardness variation of $2124 \mathrm{Al}$ alloy and $2124 \mathrm{Al}$ alloy $+20 \%$ volume fractions of $\delta-\mathrm{A}_{2} \mathrm{O}_{3}$ composite as a function of aging time at $190{ }^{\circ} \mathrm{C}$ after solution treatment at: a) $495{ }^{\circ} \mathrm{C}$ and b) $555{ }^{\circ} \mathrm{C}$

Slika 5: Spreminjanje mikrotrdote $\mathrm{Al}$ zlitine 2124 in Al kompozita $2124+20 \%$ volumenskega deleža $\delta-\mathrm{Al}_{2} \mathrm{O}_{3}, \mathrm{v}$ odvisnosti od časa staranja na $190{ }^{\circ} \mathrm{C}$, po raztopnem žarjenju na: a) $495{ }^{\circ} \mathrm{C}$ in b) $555^{\circ} \mathrm{C}$

ditions, the unreinforced $2124 \mathrm{Al}$ matrix alloy and the composite reached a peak hardness after aging for 10-12 h and 7-9 h, respectively, at $190{ }^{\circ} \mathrm{C}$. A reduced hardness of the matrix was observed in the case of the reinforced alloy.

The times required to attain the peak hardness for both alloys artificially aged between $160{ }^{\circ} \mathrm{C}$ and $190{ }^{\circ} \mathrm{C}$ are summarized in Table 2. First, the peak of the matrix microhardness values of the composite samples increase with increasing solutionizing temperature, while these values show a slight decrease in the unreinforced 2124 Al matrix. Second, the presence of short alumina fibers in the matrix decreases the time needed to achieve the peak microhardness. This suggests that the addition of $20 \%$ volume fractions of $\delta-\mathrm{A}_{2} \mathrm{O}_{3}$ short fibers for the matrix causes considerable acceleration in the aging kinetics of the matrix alloy. Third, a decrease in the aging temperature from $190{ }^{\circ} \mathrm{C}$ to $170{ }^{\circ} \mathrm{C}$ leads to an increase of the peak microhardness of the composite matrix. From Table 2, solutionizing at $495{ }^{\circ} \mathrm{C}$ for $6 \mathrm{~h}$, followed by water quenching and aging at $190{ }^{\circ} \mathrm{C}$ for $10 \mathrm{~h}$, seems to be the best aging procedure for the unreinforced matrix alloy. In the case of the reinforced alloy the highest $\mathrm{HV}$ value was formed after solutionizing at $555^{\circ} \mathrm{C}$ for $6 \mathrm{~h}$, quenching and aging at $170{ }^{\circ} \mathrm{C}$ for $12 \mathrm{~h}$. 
Table 2: Times (h) required to attain peak hardness for $2124 \mathrm{Al}$ and $2124 \mathrm{Al}+20 \%$ volume fractions of $\delta-\mathrm{Al}_{2} \mathrm{O}_{3}$ composite matrices at different aging temperatures

Tabela 2: Čas (h) potreben za doseganje najvišje trdote Al zlitine 2124 in kompozita Al zlitine $2124+20 \%$ volumenskega deleža $\delta-\mathrm{Al}_{2} \mathrm{O}_{3}$ pri različnih temperaturah staranja

\begin{tabular}{|c|c|c|c|c|c|}
\hline $\begin{array}{c}\text { Solution } \\
\text { temp. }\left({ }^{\circ} \mathrm{C}\right)\end{array}$ & \multicolumn{5}{|c|}{ Time (h) / Microhardness $\left(\mathrm{HV}_{0.025}\right)$} \\
\hline \multirow{3}{*}{495} & Material & $160{ }^{\circ} \mathrm{C}$ & $170{ }^{\circ} \mathrm{C}$ & $180{ }^{\circ} \mathrm{C}$ & $190{ }^{\circ} \mathrm{C}$ \\
\cline { 2 - 6 } & $2124 \mathrm{Al}$ & $20 / 132.0$ & $17 / 130.4$ & $12 / 133.0$ & $10 / 133.3$ \\
\hline \multirow{3}{*}{525} & $\begin{array}{c}2124 \mathrm{Al} \\
\text { composite }\end{array}$ & $12 / 118.8$ & $12 / 119.6$ & $10 / 117.9$ & $8 / 116.7$ \\
\cline { 2 - 6 } & $\begin{array}{c}2124 \mathrm{Al} \\
\text { composite }\end{array}$ & $20 / 130.6$ & $16 / 129.6$ & $12 / 130.7$ & $8 / 132.5$ \\
\hline \multirow{3}{*}{555} & $2124 \mathrm{Al}$ & $20 / 127.5$ & $16 / 129.1$ & $10 / 129.6$ & $8 / 130.5$ \\
\cline { 2 - 6 } & $\begin{array}{c}2124 \mathrm{Al} \\
\text { composite }\end{array}$ & $12 / 128.4$ & $12 / 130.4$ & $8 / 125.8$ & $8 / 124.5$ \\
\hline
\end{tabular}

\subsection{Discussion}

The use of an Al-Cu-Mg alloy for fabricating an aluminum matrix composite leads to the formation of intermetallic particles of $\mathrm{Cu}_{2} \mathrm{Mn}_{3} \mathrm{Al}_{20}$ type. Increasing the solution treatment temperature caused greater dissolution of the $\mathrm{Cu}-\mathrm{Mn}$-Al-based intermetallic particles, and this is related to a decrease in the number of particles on the metallographic polished and etched sample surfaces. At $525{ }^{\circ} \mathrm{C}$ and $555^{\circ} \mathrm{C}$ for the solution-treated unreinforced alloy and the composites, surface blistering was observed after quenching. However, the amount of blistering was observed to be more in the unreinforced alloy when compared with the composite. These blisters were suggested to form due to a high internal gas pressure. Above the solution treatment of $495{ }^{\circ} \mathrm{C}$ for the unreinforced alloy, grain-boundary melting was detected. For $2124 \mathrm{Al}+$ $20 \%$ volume fractions of $\delta-\mathrm{Al}_{2} \mathrm{O}_{3}$ the composite specimens intermetallic dissolution was almost complete at $555^{\circ} \mathrm{C}$.

Regarding the heat-treated samples, the extensive dissolution of the $\mathrm{Cu}_{2} \mathrm{Mn}_{3} \mathrm{Al}_{20}$-type intermetallics and the formation of coherent precipitates after aging, indicate an apparently good solution and precipitation treatment that improves the hardness values of the $2124 \mathrm{Al}$ matrix. At solution-treatment temperatures above $495{ }^{\circ} \mathrm{C}$ the peak hardness values of the matrix alloy decrease, probably as a result of increasing the amount of gas porosity due to hydrogen absorption from a moist atmosphere. The increment in the peak hardness values of the composite was observed by increasing the solution-treatment temperature.

The thermal analysis technique was employed to study the change in the enthalpy, which is associated with the formation and dissolution of the precipitates. The area of the peak in the DSC curve gives the reaction enthalpy, which is directly related to the molar heat of reaction and the volume fraction of the precipitating or dissolving phase. The corresponding temperature is related to the stability of the precipitates and to the reaction kinetics. The DSC curves show that the GP zone's formation peak is suppressed in the composite matrix.
This inhibition of the GP zone's formation and its effect on the age hardening are similar to the observation of sintered aluminum powder (SAP) alloys. ${ }^{3}$ In SAP alloys, these phenomena have been attributed to a lack of quenched-in vacancies that were soaked up by the grain boundaries in the fine-grain matrix and by the $\mathrm{Al} / \mathrm{A}_{2} \mathrm{O}_{3}$ particle interfaces. The observations in the present work suggest that a similar mechanism is responsible for the inhibition of the GP zone's formation in aluminum matrix composite matrices. From the DSC scans and microhardness measurements, it was observed that the $S$ ' formation temperature is lower in the composite than in the unreinforced matrix alloy. In general, the addition of $\delta$ - $\mathrm{A}_{2} \mathrm{O}_{3}$ fibers decreases the time required to attain peak hardness. These features encourage the nucleation of precipitates by reinforcing the ceramic phase. The addition of $\delta-\mathrm{Al}_{2} \mathrm{O}_{3}$ fibers to the 2124 alloy was also resulted to obtain lower age-hardening temperatures to attain time to require peak aging. It is well known that $\delta-\mathrm{A}_{2}{ }_{2} \mathrm{O}_{3}$ fibers lead to acceleration in the aging kinetics and some possible reasons for the acceleration of the aging kinetics are given in ${ }^{21,22}$. Composite matrix has finer grains than that of the unreinforced alloy. As also evidenced from the transmission electron microscopy studies by C. M. Friend and S. D. Luxton ${ }^{23}$, the dislocation densities are almost similar in the aluminum matrix alloy and its $\delta-\mathrm{Al}_{2} \mathrm{O}_{3}$ short-fiber-reinforced composites. The dislocations in the matrix are in the form of long lines and short lines in the composite. However, the short dislocations are agglomerated close to the fiber matrix interfaces. In this study, it is suggested that these dislocations can also accelerate the formation of the S' phase. In addition, fiber matrix interfaces are well-known heterogeneous nucleation sites for precipitation.

In the as-quenched condition, the microhardness of the composite matrix is lower than that of the unreinforced matrix. The result is similar to the 2024 $\mathrm{Al}-\delta-\mathrm{A}_{2} \mathrm{O}_{3}$ composites and $2124 \mathrm{Al}-\mathrm{SiC}$ composites that were reported by K. C. Chen and C. G. Chao ${ }^{3}$ and T. S. Christman and Suresh ${ }^{16}$, respectively. When the composite is cooled from the elevated temperature of the aging process, misfit strains occur due to differential thermal contraction at the reinforcement/matrix interface, which are sufficient to generate dislocations. The dislocation density is able to influence the microhardness. B. Dutta and M. K. Surappa ${ }^{11}$ suggested an enhanced dislocation density in the $6061 \mathrm{Al}-\mathrm{A}_{2} \mathrm{O}_{3}$ composite matrix that contributes to higher microhardness values compared to the unreinforced matrix alloy. K. C. Chen and C. G. Chao ${ }^{3}$ reported that a very low dislocation density was observed in a $2024 \mathrm{Al}$ alloy that was reinforced with $\delta$ - $\mathrm{A}_{2} \mathrm{O}_{3}$ short fibers when compared with Al-SiC systems. They pointed out that the coefficient of thermal expansion difference between $\mathrm{Al}$ and $\delta$ - $\mathrm{A}_{2} \mathrm{O}_{3}$ is $3: 1$, but this ratio is $10: 1$ for $\mathrm{Al}$ and $\mathrm{SiC}$. Thus, a lower dislocation density is established in the matrix of Al- $\delta-\mathrm{A}_{2} \mathrm{O}_{3}$ short-fiber composites. Moreover, the porosity level is expected to be higher in the composite matrix due to poor wetting of the short fiber by the 
matrix during the squeeze-casting process route since the fibers are agglomerated in some regions. Since the artificial age hardening of $2124 \mathrm{Al}$ is attributed to the GP zone and the S' phase, the microhardness of the composites is smaller due to the suppression of the GP zones. Consequently, the number of S' precipitates in the composite matrix decreases. The increasing number of precipitates are expected to result in high strength in the age-hardenable alloys and their composites. The response of the $\delta-\mathrm{Al}_{2} \mathrm{O}_{3}$ short-fiber-reinforced $2124 \mathrm{Al}$ alloy matrix to aging is significantly different to that of the unreinforced alloy in the $495{ }^{\circ} \mathrm{C}$ solution-treated condition. The grain boundaries and the addition of fiber-matrix interfaces were thought to be the preferred site for pore nucleation for the following reasons; i) the incipient melting that occurs there (incipient melting is particularly prone to gas porosity because of the higher solubility in the liquid phase ${ }^{9}$ and, ii) the observation that when an aluminum matrix composite was charged with hydrogen, the gas migrates to the clusters in addition to the $\delta-\mathrm{A}_{2}{ }_{2} \mathrm{O}_{3}$ fiber interfaces. ${ }^{24}$

\section{CONCLUSIONS}

Increasing the solution treatment temperature led to an increase in the dissolution of the intermetallic particles in the composite matrix. At temperatures above $525{ }^{\circ} \mathrm{C}$, samples of the unreinforced alloy experienced significant incipient melting along the grain boundaries. The $\delta-\mathrm{Al}_{2} \mathrm{O}_{3}$ reinforced composite exhibits no grainboundary melting, but appears to show incipient melting around the short alumina fiber interfaces.

The microhardness values of the matrix of the composite were lower than that of the 2124 unreinforced matrix in their peak-aged conditions. The highest microhardness value was obtained after solutionizing at $495{ }^{\circ} \mathrm{C}$ for $6 \mathrm{~h}$, and aging at $190{ }^{\circ} \mathrm{C}$ for $10 \mathrm{~h}$ for the unreinforced matrix alloy. The highest $\mathrm{HV}$ value was found after solutionizing at $555{ }^{\circ} \mathrm{C}$ for $6 \mathrm{~h}$ and aging at $170{ }^{\circ} \mathrm{C}$ for $12 \mathrm{~h}$ for the composite.

\section{REFERENCES}

${ }^{1}$ A. Daoud, W. Reif, Influence of $\mathrm{Al}_{2} \mathrm{O}_{3}$ particulate on the aging response of A356 Al-based composites, J. Mater. Process. Tech, 123 (2002) 2, 313-318, doi:10.1016/S0924-0136(02)00103-6

${ }^{2}$ J. S. Lin, P. X. Li, R. J. Wu, Aging evaluation of cast particulate-reinforced SiC/Al (2024) composites, Scr. Metall. Scr. Metall. Mater, 28 (1993) 3, 281-286, doi:10.1016/0956-716X(93)90428-U

${ }^{3}$ K. C. Chen, C. G. Chao, Effect of $\delta$ alumina fibers on the aging characteristics of 2024-based metal-matrix composites, Metall. Mater Trans A., 26 (1995), 1035-1043, doi:10.1007/BF02670599

${ }^{4}$ K. Sukumaran, K. K. Ravikumar, S. G. K. Pillai, T. P. D. Rajan, M Ravi, R. M. Pillai, B. C. Pai, Studies on squeeze casting of Al 2124 alloy and 2124-10\% SiCp metal matrix composite, Mater. Sci. Eng. A., 490 (2008), 235-241, doi:10.1016/j.msea.2008.01.054

${ }^{5}$ J. Peng, D. H. W. Li, J. Du, Y. Xie, G. Liu, Study on the yield behavior of A12 O3-SiO2 (sf)/Al-Si metal matrix composites, Mater. Sci. Eng. A., 486 (2008), 427-432, doi:10.1016/j.matchar.2007.08.007
${ }^{6}$ J. Wang, D. Yi, X. Su, F. Yin, Influence of deformation ageing treatment on microstructure and properties of aluminum alloy 2618 , Mater. Charact., 59 (2008), 965-968, doi:10.1016/j.matchar.2007. 08.007

${ }^{7}$ M. Emamy, A. Razaghian, H. R. Lashgari, R. Abbasi, The effect of $\mathrm{Al}-5 \mathrm{Ti}-1 \mathrm{~B}$ on the microstructure, hardness and tensile properties of $\mathrm{Al}_{2} \mathrm{O}_{3}$ and SiC-containing metal-matrix composites, Mater. Sci. Eng. A, 485 (2008), 210-217, doi:10.1016/j.msea.2007.07.090

${ }^{8}$ S. C. Sharma, S. Sastry, M. Krishna, Effect of aging parameters on the micro structure and properties of ZA-27/aluminite metal matrix composites, J. Alloy Compd., 346 (2002), 292-301, doi:10.1016/ S0925-8388(02)00528-5

${ }^{9}$ M. P. Thomas, J. E. King, Effect of thermal and mechanical processing on tensile properties of powder formed 2124 aluminium and $2124 \mathrm{Al}-\mathrm{SiC}_{\mathrm{p}}$ metal matrix composite, Mater. Sci. Technol., 9 (1993), 742-753

${ }^{10}$ S. Suresh, T. Christman, S. Sugimura, Accelerated aging in cast Al alloy-SiC particulate composites, Scr. Metall. Mater., 23 (1989), 1599-1602, doi:10.1016/0036-9748(89)90136-1

${ }^{11}$ B. Dutta, M. K. Surappa, Age-hardening behaviour of Al-CuSiCp composites synthesized by casting route, Scr. Metall. Mater., 32 (1995) 5, 731-736, doi:10.1016/0956-716X(95)91594-F

${ }^{12}$ V. Massardier, L. Pelletier, P. Merle, Influence of the introduction of ceramic particles in Al-Cu alloys on GP zone formation, Mater. Sci. Eng. A., 2491 (1998), 21-133, doi:10.1016/S0921-5093(98)00577-2

${ }^{13}$ A. Mazahery, M. O. Shabani, Mechanical properties of squeeze-cast A356 composites reinforced with $\mathrm{B}_{4} \mathrm{C}$ particulates, JMPEG, 21 (2011), 247-252, doi:10.1007/s11665-011-9867-6

${ }^{14}$ I. Sahin, A. A. Eker, Analysis of microstructures and mechanical properties of particle reinforced $\mathrm{AlSi}_{7} \mathrm{Mg}_{2}$ matrix composite materials, JMPEG, 20 (2010), 1090-1096, doi:10.1007/s11665-0109738-6

${ }^{15}$ S. J. Qu, L. Geng, G. J. Cao, T. Q. Lei, Fabricating a 15 vol. \%-3.5 $\mu \mathrm{m}-\mathrm{SiCp} / \mathrm{Al}$ composite by a squeeze casting technique, J. Mater. Sci., 39 (2004), 2967-2969, doi:10.1023/B:JMSC.0000021494. 55123.e1

${ }^{16}$ T. Christman, S. Suresh, Microstructural development in aluminum alloy-SiC whisker composite, Acta Metall., 36 (1988) 7, 1691-1704, doi:10.1016/0001-6160(88)90236-2

${ }^{17}$ C. Badini, F. Marino, E. Verne, Calorimetric study on precipitation path in 2024 alloy and its SiC composite, Mater. Sci. Eng. A., 191 (1995), 185-191, doi:10.1016/0921-5093(94)09637-C

${ }^{18}$ S. K. Varma, D. Salas, E. Corral, E. Esquivel, K. K. Chawla, R. Mahapatra, Microstructural development during aging of 2014 aluminum alloy composite, J Mater Sci., 34 (1999), 1855-1863, doi:10.1023/A:1004527729424

${ }^{19}$ A. P. Sanino, H. J. Rack, Effect of reinforcement size on age hardening of PM 2009 Al-SiC 20 vol\% participate composites, J. Mater. Sci., 30 (1995), 4316-4322, doi:10.1007/BF00361511

${ }^{20}$ Heat Treatment of Aluminum Alloys, ASM Handbook, 4th ed., ASM International, 1997, 845

${ }^{21}$ Y. Song, T. N. Baker, Accelerated aging processes in ceramic reinforced AA 6061 composites, Mater. Sci.\& Tech., 10 (1994), 406-413, doi:10.1179/mst.1994.10.5.406

${ }^{22} \mathrm{~K}$. Chen, C. Chao, Effect of $\delta$ alumina fibers on the aging characteristics of 2024-based metal-matrix composites, Metall.\& Mater. Trans. A., 26a (1995), 1035-1043, doi:10.1007/BF02670599

${ }^{23}$ C. M. Friend, S. D. Luxton, The effect of $\delta$ alumina fibre arrays on the age-hardening characteristics of an Al-Mg-Si alloy, J. Mater. Sci., 23 (1988), 3173-3180, doi:10.1007/BF0055129

${ }^{24}$ C. P. You, M. Dollar, A. W. Thompson, Microstructure property relationships and hydrogen effects in a particulate-reinforced aluminum composite, Metall. Trans. A., 22 (1991), 2445-2450, doi:10.1007/ BF02665010 